\title{
BIBLIOMETRIC ANALYIS OF ARTIFICIAL INTELLIGENCE IN BUSINESS ECONOMICS
}

\author{
Ivan Novak ${ }^{13}$
}

UDC / UDK: 025.4036:004.78:004.8:33

JEL classification / JEL klasifikacija: A1, O

DOI: https://doi.org/10.22598/pi-be/2019.13.2.131

Scientific review / Pregledni znanstveni rad

Received / Primljeno: October 14, 2019 / 14. listopada 2019.

Accepted for publishing / Prihvaćeno za tisak: November 20, 2019 / 20. studenog 2019.

\section{Summary}

Invention of artificial intelligence (AI) is certainly one of the most promising technological advancements in modern economy. General AI reaching singularity makes one imagine its disruptive influence. Once invented it is supposed to surpass all human cognitive capabilities. Nevertheless, narrow AI has already been widely applied encompassing many technologies. This paper aims to explore the research area of artificial intelligence with the emphasis on the business economics field. Data has been derived from the records extracted from the Web of Science which is one of the most relevant databases of scientific publications. Total number of extracted records published in the period from 1963-2019 was 1369. Results provide systemic overview of the most influential authors, seminal papers and the most important sources for AI publication. Additionally, using MCA (multiple correspondence analysis) results display the intellectual map of the research field.

Keywords: artificial intelligence, business economics, content analysis, bibliometrics, HOMALS.

* Paper presented at International Scientific Conference „TRADE PERSPECTIVES 2019: Business model innovations in domestic and international trade", November 2829, 2019, Zagreb, Croatia. Abstract of paper published in Conference Proceedings.

${ }^{13}$ Ivan Novak, PhD, Assistant Professor, Department of International Economics, Faculty of Economics and Business, University of Zagreb, Croatia, E-mail: inovak@efzg.hr 


\section{INTRODUCTION}

Similar to previous technological revolutions artificial intelligence is expected to fundamentally change the way of doing business (Makridakis, 2017). Idea of harvesting a system that could properly understand available data, learn from it and accomplish predefined goals has been a topic of many boardrooms and business forums. Experience from industry, governments and universities have already demonstrated some positive effects of artificial intelligence application (Kaplan \& Haenlein, 2019). Digital transformation fueled with development of mobile and Internet technologies have created a new economic environment branded with streamline operations and improved customer experience (Warner \& Wäger, 2019). In search for more efficiency businesses have started to open cloud operations. Even some governments have followed this business trend and developed their online platforms. Terms such as e-commerce, e-banking, ecitizens and e-signature have nowadays created entirely new level of efficiency in private and business environment (Dirican, 2015). Implementation of AI may bring many rewards however to avoid negative consequences like job insecurity and rising inequality Nam (2019) has suggested gradual and supervised transition.

This paper aims to derive a systemic view of the AI application in business and economics. Results of the research reveal the most influential authors, seminal papers and the most important sources for AI publication. Additionally, results reveal intellectual structure of the research field.

Remainder of the paper is organized in four sections. Second part of this paper is about previous research examining AI application. Third part of the paper is about methodological approach developed for mapping the research field. Fourth part of the paper demonstrates the results of the research. Conclusion of the paper follows up with short discussion of the relevant findings, limitations and potential future research avenues.

\section{LITERATURE REVIEW}

There are different types of AI technology and therefore expectations regarding its disruptive nature may considerably vary. According to Kaplan \& Haenlein (2019) artificial intelligence may be analytical, human-inspired or even humanized. If mentioned properties are fully utilized its effect may be nothing less than disruptive. Nevertheless, industry leaders are left with little practical advice on how to harvest this potential. AI is typically implemented accompanying other digital technologies. These types of projects are commonly deployed aiming to support existing operations therefore demystifying 
exaggerated claims about AI's unprecedented effect (Brock \& Von Wangenheim, 2019). Nevertheless, Sremac et al. (2019) explain that highly complex problems with stochastic properties are not easily solved with traditional methods while AI successfully does the challenge. Corea (2019) highlights several areas with positive experience regarding artificial intelligence including speech recognition, financial industry and insurance. According to Fountain, McCarthy \& Saleh (2019) AI is being applied in everything from agriculture to banking. Many other industries also place great expectation toward artificial intelligence. AI enhanced machinery is expected to eradicate boring jobs and make the remaining workforce more productive. Interplay of artificial intelligence, robots and human creativity is expected to achieve another level of proficiency (Holford, 2019). Artificial intelligence has enabled conceiving innovations ranging from autonomous vehicles manufacturing to the autonomous enterprise creation (Barro \& Davenport, 2019). Velencei claims (2019) that artificial intelligence capabilities are expanding from mechanical and analytical toward thinking. Combination of some AI strands like machine vision, natural language processing, big data and robotics could be used to boost quality of decision making in almost any organization (Kliman \& Arinze, 2019). Fountain, McCarthy \& Saleh (2019) emphasized that in order to further increase the success of implementing AI organizations should abandon traditional mindset and intensively focus on education of the workforce, accounting for complexity, business readiness and innovation capacity. Intensive implementing of AI without considering its role in innovation of products, services, processes and business models may not necessarily give the best results. Organizational strategy for technological advancement should account for meaningful investments with specific emphasis on the workforce training and necessary skill development (Barro \& Davenport, 2019). While the AI is being deeply incorporated into organizational activities importance of emotional intelligence of the workforce is growing and humans are settling with interpersonal skills and empathy. Human workforce has always been an integral part of any organization but since AI is mastering mechanics and analytics importance of emotional intelligence is rising (Huang, Rust \& Maksimovic, 2019). This type of approach would make humans valid partners in technological transformation and it would nurture human-oriented organizations (Holford, 2019).

\section{METHODOLOGY}

Bibliometric data collection was carried out using the Web of Science Core Collection citation database developed by Clarivate Analytics including several indexes: 
AHCI, BCI-S, BCI-SS\&H, CPCI-S, CPCI-SS\&H, CCR, ESCI, ESCI B, IC, SCIE and SCCI.

In order to collect the data following query was design: TS="artificial intelligence". First database result included a wide range of records from all research areas encompassing 37613 records. Largest research fields were: Computer science (16520), Engineering (11974), Automation control systems, Telecomunications (1670), Science technology other topics (1508) and Operations research management science (1506). Business economics was the sixth largest research area with 1369 records. Research areas are not mutually exclusive and therefore one record may fit in more than one research area. Nevertheless, in order to closely examine the AI business economics application further specification was given by extracting only those records. Since the field of artificial intelligence is rather dynamic this research includes information not only from academic journals but also proceedings, book reviews, editorials, book chapters, reviews, meeting abstracts, early access, discussions and books covering period from the first Web of science digital records of the topic in 1963 to the present of September 2019. On $17^{\text {th }}$ of September 2019 total number of 1369 records was selected from the Web of Science Core Collection database.

Following the selection of records list of accompanying keywords chosen by authors were extracted from the database output (see Appendix 1). There was total of 3257 unique keywords. In order for the keyword to represent a topic it should appear at least twice in keywords and at least five times in records. List was further examined manually in order to filter general words and phrases not reflecting AI business and economics application. This process generated a total of 176 topics. These topics have been cross-referenced with content of each record containing title, abstract and keywords. Depending on if the topic was found in the content of the record binary value was given to each field connecting database record and selected topic ( 1 if the topic was found in the record and 0 otherwise). This process created a matrix ((number of topics) $\mathrm{x}$ (number of records); 176x1369)) with binary values imported to statistical software to conducted HOMALS procedure for multiple correspondence analysis (MCA). MCA was found very useful in analyzing content data aiming to create the intellectual map of the research field (Furrer et al, 2008; Marzi et al., 2017; Demiroz \& Haase, 2019). Procedure derives coordinates for two-dimensional map aiming to visualize the research field of artificial intelligence in the realm of business and economics. Coordinates are based on the number of mutual appearances of the selected topics in the AI database records. Topics appearing closer together create clusters mirroring subfields of the research area (Bendixen, 1995). Based on the topic total number of appearances map of the field was divided in two dimensions: first showing popular topics and second showing emerging topics and 
relevant literature gaps. Furthermore, the size of the keyword bubble reflects its relative importance (see the list of keywords in Appendix 1).

By applying this approach results offers stats which are not directly accessible from the database itself and offer insightful intellectual map of the research field body and bibliometric data analysis.

\section{RESULTS AND DISCUSSION}

Significant increase in the general number of scientific publication may be detected in two periods: one starting in 1990 and second in 2000 (Johnson, Watkinson \& Mabe, 2018). Nevertheless, research area of artificial intelligence has proliferated not earlier then 2015 when the number of publication per year doubled reaching 70 records. Since then the number of publications was increasing and in 2017 there was 64 new records (see Figure 1). Total publication of artificial intelligence in the realm of business and economics in the period from 1963 to September 2019 in the Web of Science database has reached 1369 records. This information indicates the novelty of the research area producing intellectual map of the research field may help visualize its development.

Figure 1. Evolution of AI publications

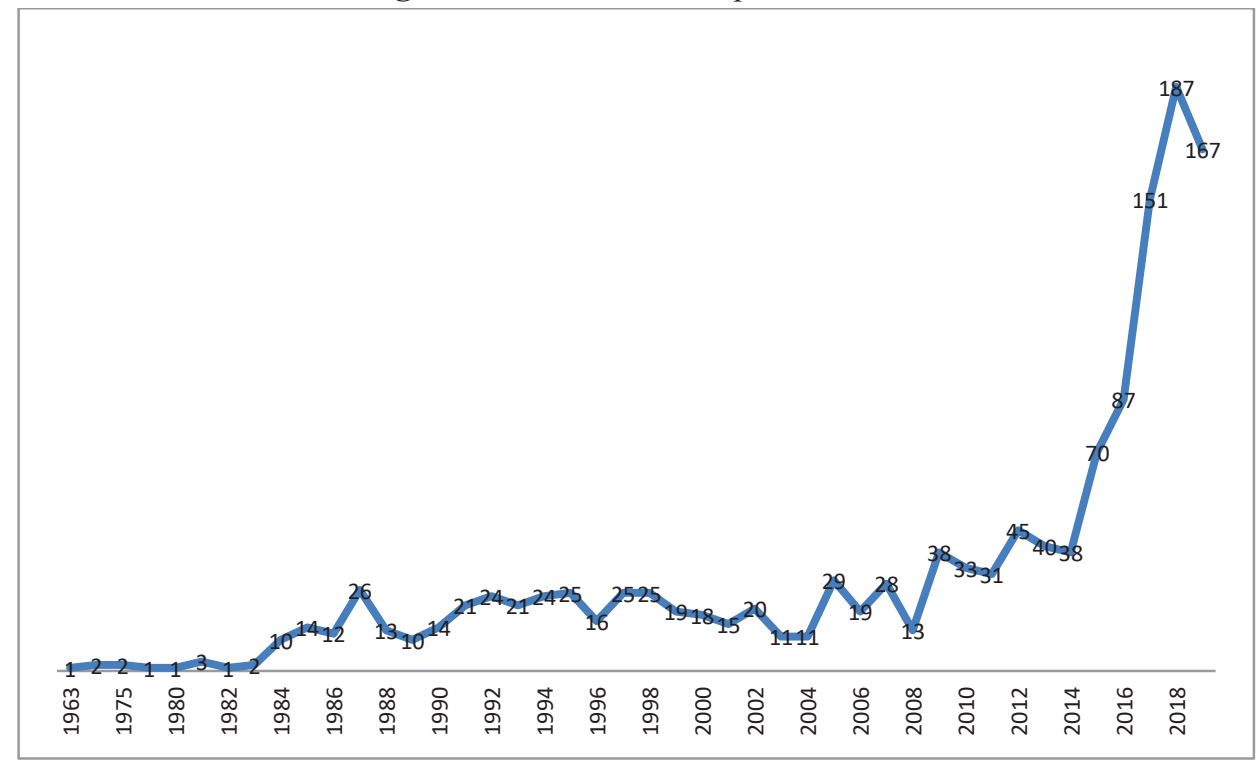

Source: Web of Science, author calculation 
Prior to intellectual map of the research field it is very useful to detect the most influential authors, seminal papers and the most important sources outlining the research field. The most cited author was the Tam K.Y. who published two papers. First paper was co-authored with Kiang, M.Y. tackling the use of neural networks for nonlinear discriminant analysis in predicting bank failure (cited 532 times). Tam \& Kiang (1992) demonstrated promising properties of neural networks in evaluating bank crisis. Second paper was about genetic algorithms, function optimization, and facility layout design. Tam (1992) argued that genetic algorithms may be used for answering large scale layout difficulties (cited 104 times).

Kiang, M.Y. published two papers. One already mentioned and the other coauthored with Kulkarni, U.R. discussing dynamic grouping of parts in flexible manufacturing systems using a self-organizing neural networks approach (cited 26 times). Kulkarni and Kiang (1995) tested a special type of neural network designed for intelligent grouping of parts and machines. Tool has been proven useful and applicable in flexible manufacturing systems.

Other most cited authors have published only a single paper but nevertheless with highest impact in the research field. Sadeh, Smith, and Swaminathan (1998) explored modeling supply chain dynamics with multi-agent approach. They presented a contribution in methodology improvement for simulation and management decision in creating more effective supply chains systems (cited 405 times).

Jain \& Meeran (1999) took a subset of job scheduling problems and provided a historical summary of applied approaches and scholars involved in deterministic job-shop scheduling (cited 385 times).

Chen \& Das (2007) tried to perform sentiment extraction from Yahoo small talk. This being a hard semantic problem they used a combination of various classifiers combining with voting schemes. Due to similar accuracy of Bayesian method they recommend using approach for sentiment estimation regarding press release, board announcements, third party news and regulation change (cited 331 times).

Finally, Marco, Varetto, \& Altman (1994) compared the results of linear discriminant and logit analyses with neural networks for detecting corporate distress. In the period 1982-1992 procedure was applied to thousand companies including high and low quality subjects. Accuracy was over $90 \%$ but authors emphasize the black-box problem and training overfitting with a negative impact on later prediction (cited 330 times) (see Table 2). 
Table 1. List of 10 most influential authors

\begin{tabular}{|l|l|l|l|l|}
\hline Author & $\begin{array}{l}\text { Number of } \\
\text { papers }\end{array}$ & $\begin{array}{l}\text { Minimun } \\
\text { citation }\end{array}$ & $\begin{array}{l}\text { Max } \\
\text { citation }\end{array}$ & Cumulative \\
\hline Tam, KY & 2 & 104 & 532 & 636 \\
\hline Kiang, MY & 2 & 26 & 532 & 558 \\
\hline Sadeh, NM & 1 & 405 & 405 & 405 \\
\hline Smith, SF & 1 & 405 & 405 & 405 \\
\hline $\begin{array}{l}\text { Swaminathan, } \\
\text { JM }\end{array}$ & 1 & 405 & 405 & 405 \\
\hline Meeran, S & 1 & 385 & 385 & 385 \\
\hline Jain, AS & 1 & 385 & 385 & 385 \\
\hline Chen, MY & 1 & 331 & 331 & 331 \\
\hline Das, SR & 1 & 331 & 331 & 331 \\
\hline Marco, G & 1 & 330 & 330 & 330 \\
\hline Varetto, F & 1 & 330 & 330 & 330 \\
\hline Altman, EI & 1 & 330 & 330 & 330 \\
\hline
\end{tabular}

Source: Web of Science, author calculation

Some of seminal papers are already mentioned as the work of the most influential authors and others are presented in the following section. LeBaron, Arthur \& Palmer (1999) used computer simulated artificial stock market where bidding was done by the AI traders. Prices were given endogenously and goal was to clear the market. Aim of the research was to confirm the features found in the real stock markets. Prices followed fundamental and technical principles. Volatility hysteresis and leptokurtosis were also present. Furthermore, agents were able to acquire rational expectations equilibrium (cited 320 times).

Zhang et al. (1999) examined the general framework and cross-validation analysis of the artificial neural networks in bankruptcy prediction. They claim that neural networks give superior results against logistic regression (cited 272 times).

Storer, Wu \& Vaccari (1992) explored new search spaces for sequencing problems applyed to job shop scheduling. They suggest using the combination of problem specific search heuristics and artificial intelligence with novel definitions of solution space and their neighborhoods in order to solve the scheduling objective minimizing the necessary time (cited 260 times).

Using operational research and artificial intelligence Fethi \& Pasiouras (2010) tried to assess bank efficiency and performance. They collected 196 papers examining 
the bank soundness and performance. Envelopment data analysis was found to be the most often used operational research technique. Other usable techniques were support vector machines, neural networks and multi-criteria decision (cited 228 times).

Finally, the last top 10 list paper was examining the history and future of the workplace automation questioning why is there still so many jobs. David (2015) argued that some journalist and experts exaggerate replacement of labor input by automation claiming that machines and labor complement each other achieving higher efficiency, more earnings and require further employment. Nevertheless, technology has changed the structure of labor demand and amplified workers inequality, specifically between those with high and low level skills. Also he argues that this trend is not likely to continue and that recent development in $\mathrm{AI}$ and robotics may eradicate boring workforce assignments and increase demand for problem solving skills and creativity.

Table 2. List of 10 most cited papers

\begin{tabular}{|l|l|l|l|l|}
\hline Author & Title & Journal name & Cit. & Year \\
\hline $\begin{array}{l}\text { Tam, KY; } \\
\text { Kiang, MY }\end{array}$ & $\begin{array}{l}\text { Managerial applications of } \\
\text { neural networks - The case of } \\
\text { bank failure predictions }\end{array}$ & $\begin{array}{l}\text { Management } \\
\text { Science }\end{array}$ & 532 & 1992 \\
\hline $\begin{array}{l}\text { Swaminathan, } \\
\text { JM; Smith, SF; } \\
\text { Sadeh, NM }\end{array}$ & $\begin{array}{l}\text { Modeling supply chain } \\
\text { dynamics: A multi-agent } \\
\text { approach }\end{array}$ & $\begin{array}{l}\text { Decision } \\
\text { Sciences }\end{array}$ & 405 & 1998 \\
\hline $\begin{array}{l}\text { Jain, AS; } \\
\text { Meeran, S }\end{array}$ & $\begin{array}{l}\text { Deterministic job-shop } \\
\text { scheduling: Past, present and } \\
\text { future }\end{array}$ & $\begin{array}{l}\text { European Journal } \\
\text { of Operational } \\
\text { research }\end{array}$ & 385 & 1999 \\
\hline $\begin{array}{l}\text { Das, SR; Chen, } \\
\text { MY }\end{array}$ & $\begin{array}{l}\text { Yahoo! for Amazon: Sentiment } \\
\text { extraction from small talk on } \\
\text { the web }\end{array}$ & $\begin{array}{l}\text { Management } \\
\text { Science }\end{array}$ & 331 & 2007 \\
\hline $\begin{array}{l}\text { Altman, EI; } \\
\text { Marco, G; } \\
\text { Varetto, F }\end{array}$ & $\begin{array}{l}\text { Corporate distress diagnosis - } \\
\text { comparisons using linear } \\
\text { discriminant-analysis and } \\
\text { neural networks (the Italian } \\
\text { experience) }\end{array}$ & $\begin{array}{l}\text { Journal of } \\
\text { Banking \& } \\
\text { Finance }\end{array}$ & 330 & 1994 \\
\hline $\begin{array}{l}\text { LeBaron, B; } \\
\text { Arthur, WB; } \\
\text { Palmer, R }\end{array}$ & $\begin{array}{l}\text { Time series properties of an } \\
\text { artificial stock market }\end{array}$ & $\begin{array}{l}\text { Journal of } \\
\text { Economic } \\
\text { Dynamics \& } \\
\text { Control }\end{array}$ & 320 & 1999 \\
\hline
\end{tabular}




\begin{tabular}{|l|l|l|l|l|}
\hline $\begin{array}{l}\text { Zhang, GQ; } \\
\text { Hu, MY; } \\
\text { Patuwo, BE; } \\
\text { Indro, DC }\end{array}$ & $\begin{array}{l}\text { Artificial neural networks in } \\
\text { bankruptcy prediction: General } \\
\text { framework and cross-validation } \\
\text { analysis }\end{array}$ & $\begin{array}{l}\text { European Journal } \\
\text { of Operational } \\
\text { Research }\end{array}$ & 272 & 1999 \\
\hline $\begin{array}{l}\text { Storer, RH; } \\
\text { WU, SD; } \\
\text { VACCARI, R }\end{array}$ & $\begin{array}{l}\text { New search spaces for } \\
\text { sequencing problems with } \\
\text { application to job shop } \\
\text { scheduling }\end{array}$ & $\begin{array}{l}\text { Management } \\
\text { Science }\end{array}$ & 260 & 1992 \\
\hline $\begin{array}{l}\text { Fethi, MD; } \\
\text { Pasiouras, F }\end{array}$ & $\begin{array}{l}\text { Assessing bank efficiency and } \\
\text { performance with operational } \\
\text { research and artificial } \\
\text { intelligence techniques: A } \\
\text { survey }\end{array}$ & $\begin{array}{l}\text { European Journal } \\
\text { of Operational } \\
\text { research }\end{array}$ & 228 & 2010 \\
\hline David, H & $\begin{array}{l}\text { Why Are There Still So Many } \\
\text { Jobs? The History and Future } \\
\text { of Workplace Automation }\end{array}$ & $\begin{array}{l}\text { Journal of } \\
\text { economic } \\
\text { perspectives }\end{array}$ & 211 & 2015 \\
\hline
\end{tabular}

Source: Web of Science, author calculation

As the Figure 1 demonstrates, highest portion of literature in artificial intelligence in business economics was published recently. Moreover, since technology is continuously developing nature of the examined phenomenon implies that more recent publications may be more relevant part of the literature. Nevertheless, since not all new records bear the same importance following section further examines the papers with most impact within the last three years.

Grewal, Roggeveen \& Nordfalt (2017) emphasized five important topics in retailing: analytics and profit, big data manipulation, customer preferences, visual display and inventory supply. They suggested additional examination of technologies such as AI (artificial intelligence), VR (virtual reality), AR (augmented reality), IoT (Internet of things), robots, drones and autonomous driving.

Makridakis (2017) explored forthcoming artificial Intelligence (AI) revolution and its impact on society and firms. He claimed that artificial intelligence may entirely transform the market. Customers will be able to access the global market while entrepreneurs who are willing to utilize innovative technologies and take the risk will benefit the most. He emphasizes that even though AI has the potential of society advancement it is important to avoid or at least minimize accompanying dangers such as consequential unemployment and rising wealth concentration.

Wirtz et al. (2018) examined the application of robots in the service industry. They have classified the properties of various progressive technologies used in service 
industry and distinguish between activities that are expected to be dominated by the human workforce. Furthermore, they investigated the perception of technology users and therefore improved the service robot acceptance model. Finally, they discussed the ethical problems associated with robotics in the service industry. Huang \& Rust (2018) distinguish among four levels of intelligence: mechanical task oriented, analytical, intuitive and empathic. They considered AI application to usually begin at the mechanical level replacing some part of human responsibilities. As it advances majority of the task oriented responsibilities are operated by the AI while replacement of analytics is on the horizon. Simultaneously importance of the human workforce skills is shifting from mechanical and analytical to intuitive and empathic. It is expected that AI will eventually reach the level of emotional intelligence encompassing necessary intuition and empathy therefore entirely replacing the need for human workforce.

Arntz, Gregory \& Zierahn (2017) revisited the risk of job loss to automation. They reexamined the possibility of automation replacing the half of the human workforce in the next 10-20 years. Authors claim that the extent of job loss in automotive industry to robots is overstated. If accounting for heterogeneity of jobs and adaptiveness of the human workforce, job loss should not be higher than $9 \%$.

Sagiyeval et al. (2018) researched the intellectual input of development in the knowledge-based economy and problems of measuring in countries with developing markets. High tech industries and services are growing twice as fast as manufacturing. If aiming to create knowledge based economy and utilize technological development intellectual security must be properly managed.

Kane (2017) examined the effect of social media in organizational knowledge management. He emphasized that social media is not monolithic and rather multidimensional technological infrastructure encompassing cloud computing, mobile communications and analytics. Each of these dimensions had an important transformative effect on the organizational knowledge management and technologies such as AI, VR, and $\mathrm{AR}$ are expected to drive this transformation even further.

Zhang, McBurney, Musial (2018) studied the convergence of trading strategies in continuous double auction markets with constrained rational networked traders. Trading simulation was conducted in social network artificial stock market with several canonical topologies. Participants learned from each other and portions of trading strategies became stable over time. Which strategy prevails dependents on network topology, network connections and types of traders.

Dabirian \& Kietzmann (2017) explored branding strategies that companies used to attract best employees. Using the IBM Watson authors analyze workplace reviews deriving several key points: balance between work and life, management role, salaries, advancement opportunities, meaningful application of employee skills, challenge and 
social interaction. Importance of each dimension varies depending on the overall attractiveness of the company.

Ehret \& Wirtz (2017) argued that existing business models are inadequate to utilize opportunities and manage threats arising from the recent technological development. Considering non-ownership approach they recommend developing business architecture with several properties: endowment of manufacturing assets, upkeep and repair, using big data and artificial intelligence while including the final customer in manufacturing process and supply chain system.

Table 3. List of most influential papers

\begin{tabular}{|c|c|c|c|c|}
\hline Author & Title & $\begin{array}{l}\text { Journal } \\
\text { name }\end{array}$ & Cit. & Year \\
\hline $\begin{array}{l}\text { Grewal, D; } \\
\text { Roggeveen, AL; } \\
\text { Nordfalt, J }\end{array}$ & The Future of Retailing & $\begin{array}{l}\text { Journal of } \\
\text { Retailing }\end{array}$ & 65 & 2017 \\
\hline Makridakis, S & $\begin{array}{l}\text { The forthcoming Artificial } \\
\text { Intelligence (AI) revolution: } \\
\text { Its impact on society and } \\
\text { firms }\end{array}$ & Futures & 25 & 2017 \\
\hline Huang, MH; Rust, RT & $\begin{array}{l}\text { Artificial Intelligence in } \\
\text { Service }\end{array}$ & $\begin{array}{l}\text { Journal of } \\
\text { Service } \\
\text { Research }\end{array}$ & 24 & 2018 \\
\hline $\begin{array}{l}\text { Arntz, M; Gregory, T; } \\
\text { Zierahn, U }\end{array}$ & $\begin{array}{l}\text { Revisiting the risk of } \\
\text { automation }\end{array}$ & $\begin{array}{l}\text { Economics } \\
\text { Letters }\end{array}$ & 20 & 2017 \\
\hline $\begin{array}{l}\text { Sagiyeval, R; } \\
\text { Zhuparova, A; } \\
\text { Ruzanov, R; } \\
\text { Doszhan, R; Askerov, } \\
\text { A }\end{array}$ & $\begin{array}{l}\text { Intellectual input of } \\
\text { development by } \\
\text { knowledge-based economy: } \\
\text { problems of measuring in } \\
\text { countries with developing } \\
\text { markets }\end{array}$ & $\begin{array}{l}\text { Entrepreneurs } \\
\text { hip and } \\
\text { Sustainability } \\
\text { Issues }\end{array}$ & 18 & 2018 \\
\hline $\begin{array}{l}\text { Wirtz, J; Patterson, } \\
\text { PG; Kunz, WH; } \\
\text { Gruber, T; Lu, VN; } \\
\text { Paluch, S; Martins, A }\end{array}$ & $\begin{array}{l}\text { Brave new world: service } \\
\text { robots in the frontline }\end{array}$ & $\begin{array}{l}\text { Journal of } \\
\text { Service } \\
\text { Management }\end{array}$ & 14 & 2018 \\
\hline Kane, GC & $\begin{array}{l}\text { The evolutionary } \\
\text { implications of social media } \\
\text { for organizational } \\
\text { knowledge management }\end{array}$ & $\begin{array}{l}\text { Information } \\
\text { and } \\
\text { Organization }\end{array}$ & 13 & 2017 \\
\hline
\end{tabular}




\begin{tabular}{|c|c|c|c|c|}
\hline $\begin{array}{l}\text { Zhang, JH; } \\
\text { McBurney, P; Musial, } \\
\text { K }\end{array}$ & $\begin{array}{l}\text { Convergence of trading } \\
\text { strategies in continuous } \\
\text { double auction markets with } \\
\text { boundedly-rational } \\
\text { networked traders }\end{array}$ & $\begin{array}{l}\text { Review of } \\
\text { Quantitative } \\
\text { Finance and } \\
\text { Accounting }\end{array}$ & 12 & 2018 \\
\hline $\begin{array}{l}\text { Dabirian, A; } \\
\text { Kietzmann, J; Diba, } \\
\text { H }\end{array}$ & $\begin{array}{l}\text { A great place to work!? } \\
\text { Understanding } \\
\text { crowdsourced employer } \\
\text { branding }\end{array}$ & $\begin{array}{l}\text { Business } \\
\text { Horizons }\end{array}$ & 12 & 2017 \\
\hline Ehret, M; Wirtz, J & $\begin{array}{l}\text { Unlocking value from } \\
\text { machines: business models } \\
\text { and the industrial internet of } \\
\text { things }\end{array}$ & $\begin{array}{l}\text { Journal of } \\
\text { Marketing } \\
\text { Management }\end{array}$ & 11 & 2017 \\
\hline
\end{tabular}

Source: Web of Knowledge

Examining the seminal papers and the most cited papers in the last 3 years it is possible to extrapolate some relevant major topics giving the first outline of AI business economics research field. These topics include bankruptcy prediction, supply chain management, job-shop scheduling, stock market properties, trading strategies, workforce automation replacement, retailing technology advancement, robotics in services, knowledge based economy, social media and crowdsourced employer branding.

Furthermore, with interest in the field of AI it is beneficial to differentiate publication sources. European Journal of Operational Research was the most important source of publication with 120 AI papers reaching 3679 citations. Average number of citations was 28,5 and most cited paper published in the journal was titled "Deterministic job-shop scheduling: Past, present and future" (cited 385 times). Management Science was the second most important source with the highest number of total citations 1224 publishing 10 papers with an average citation 122,4. Most cited paper published in the journal was titled "Managerial applications of neural networks - The case of bank failure predictions" (cited 532 times). Journal of Banking \& Finance was the source with the highest average citation (150) with total of 3 papers. Most cited paper in the journal was titled "Corporate distress diagnosis - comparisons using linear discriminant-analysis and neural networks (the Italian experience) (cited 330 times). Other most important sources were Decision Sciences (13 papers, 637 citations), Omega-International Journal of Management Science (42 papers, 600 citations), Journal of the Operational Research Society, International Journal of Forecasting (10 papers, 501 citations), Journal of Economic Dynamics \& Control (6 papers, 450 citations), Journal of Forecasting (7 
papers, 298 citations) and Interfaces (20 papers, 268 citations). For more details, see Table 4.

Table 4. Most influential sources

\begin{tabular}{|c|c|c|c|c|c|}
\hline & No & Min & $\operatorname{Max}$ & Sum & Mean \\
\hline $\begin{array}{l}\text { EUROPEAN JOURNAL OF } \\
\text { OPERATIONAL RESEARCH }\end{array}$ & 129 & 1 & 385 & 3679 & 28,5 \\
\hline MANAGEMENT SCIENCE & 10 & 1 & 532 & 1224 & 122,4 \\
\hline DECISION SCIENCES & 13 & 1 & 405 & 637 & 49 \\
\hline $\begin{array}{l}\text { OMEGA-INTERNATIONAL } \\
\text { JOURNAL OF MANAGEMENT } \\
\text { SCIENCE }\end{array}$ & 20 & 1 & 182 & 600 & 30 \\
\hline $\begin{array}{l}\text { JOURNAL OF THE OPERATIONAL } \\
\text { RESEARCH SOCIETY }\end{array}$ & 42 & 1 & 61 & 562 & 13,3 \\
\hline $\begin{array}{l}\text { INTERNATIONAL JOURNAL OF } \\
\text { FORECASTING }\end{array}$ & 10 & 1 & 157 & 501 & 50,1 \\
\hline $\begin{array}{l}\text { JOURNAL OF BANKING \& } \\
\text { FINANCE }\end{array}$ & 3 & 2 & 330 & 450 & 150 \\
\hline $\begin{array}{l}\text { JOURNAL OF ECONOMIC } \\
\text { DYNAMICS \& CONTROL }\end{array}$ & 6 & 3 & 320 & 390 & 65 \\
\hline JOURNAL OF FORECASTING & 7 & 1 & 192 & 298 & 42,5 \\
\hline INTERFACES & 20 & 1 & 68 & 268 & 13,4 \\
\hline
\end{tabular}

Following section of the paper illustrates intellectual map of the researched field. All topics are distributed in two maps. First map is showing popular topics and second map is showing emerging topics and relevant literature gaps. Topics are located in twodimensional space according to sub-streams of research and their relative importance. In order to increase the readability of the map densest parts are augmented.

First map is showing popular topics with at least six sub-streams of research. First sub-stream of research is described with topics such as discriminant analysis, financial crisis, bankruptcy, support vector machine and credit risk. Second sub-stream of research is described with topics such as time series, pattern recognition and pricing. Third sub-stream of research is described with topics such as neural networks, forecast, simulation, optimization, agent based models, pricing, computational intelligence and hybrid modelling. Fourth sub-stream of research is described with topics such as genetic algorithm, multi agent system and clustering. Fifth sub-stream of research is described with topics such as distributed artificial intelligence, case based reasoning, knowledge based system, expert system and decision support. Sixth sub-stream of research is 
described with topics such as operational research and scheduling. Other than mentioned sub-streams map includes topics such as manufacturing, data mining, big data, marketing, accounting, automation, virtual reality and robots (see Appendix 2 and Appendix 3).

Second map is showing emerging topics and relevant literature gaps with at least six sub-streams of research. First sub-stream of research is described with topics such as linear programming, swarm intelligence, vehicle routing, simulated annealing, dynamic programing, integer programming, tabu search. Second sub-stream of research is described with topics such as intuition, metaheuristics, influence diagrams, bounded rationality. Third sub-stream of research is described with topics such as particle swam optimization, mathematical programming, operational risk, project management. Fourth sub-stream of research is described with topics such as operations management, probabilities, belief networks, knowledge representations, performance evaluation, complex systems. Fifth sub-stream of research is described with topics such as sensitivity analysis, fuzzy sets, ANFIS, rough sets, EVOLINO, technical analysis, neural nets, evolutionary algorithms, Bayesian network and classification accuracy. Sixth sub-stream of research is described with topics such as market microstructure, business failure, financial rations, financial distress and exchange rate. Other than mentioned sub-streams map includes topics such as chatbots, augmented reality, autonomous systems, cyberspace, early warning, text mining, search engine, IBM Watson, ensemble, Industry 4.0., combinatorial optimization, particle swarm optimization, random forest, cognitive computing, evolutionary computation, soft computing, artificial general intelligence, singularity and consciousness (see Appendix 4 and Appendix 5).

\section{CONCLUSION}

Due to the high complexity of artificial intelligence development it is very difficult to establish clearly separated research fields. There are many tools of artificial intelligence and there are many industries in which these tools are utilized. Some tools are often used together and some industries use many different tools and therefore these connections are not always easily interpretable. Extensiveness of business economics utilization of AI bounds more detail insight into each of the selected application area. Future research efforts may be focused on individual tools or industries further examining specific circumstances accompanying selected area of AI application. Nevertheless, this research enables to identify the most influential authors, seminal papers and the most important sources dealing with the topic of artificial intelligence application in business and economics. Furthermore, intellectual map of the field offers some insights into 
diversity of topics and systemic literature overview regarding the application of AI in business and economics.

\section{REFERENCES:}

1. Altman, E. I., Marco, G., Varetto, F. (1994). Corporate distress diagnosis: Comparisons using linear discriminant analysis and neural networks (the Italian experience). Journal of banking \& finance, 18(3). 505-529. DOI: http://dx.doi.org/10.1016/0378-4266(94)90007-8

2. Arntz, M., Gregory, T., \& Zierahn, U. (2017). Revisiting the risk of automation. Economics Letters, 159, 157-160. DOI: http://dx.doi.org/10.1016/j.econlet.2017.07.001

3. Barro, S., \& Davenport, T. H. (2019). People and machines: Partners in innovation. MIT Sloan Management Review, 60(4). 22-28. https://search.proquest.com/docview/2273706424? accountid=132154

4. Bendixen, M. T. (1995). Compositional perceptual mapping using chi-squared trees analysis and correspondence analysis. Journal of Marketing Management, 11(6). 571-581. https://doi.org/10.1080/0267257X.1995.9964368

5. Brock, J. K. U., \& Von Wangenheim, F. (2019). Demystifying AI: What Digital Transformation Leaders Can Teach You about Realistic Artificial Intelligence. California Management Review, 61(4). 110-134. DOI: http://dx.doi.org/10.1177/1536504219865226

6. Corea, F. (2019). Applied artificial intelligence: Where AI can be used in business, Springer. DOI: http://dx.doi.org/10.1007/978-3-319-77252-3

7. Dabirian, A., Kietzmann, J., \& Diba, H. (2017). A great place to work!? Understanding crowdsourced employer branding. Business Horizons, 60(2). 197-205. DOI: http://dx.doi.org/10.1016/j.bushor.2016.11.005

8. David, H. J. J. O. E. P. (2015). Why are there still so many jobs? The history and future of workplace automation. Journal of economic perspectives, 29(3), 3-30. DOI: $10.1257 /$ jep.29.3.3

9. Das, S. R., \& Chen, M. Y. (2007). Yahoo! for Amazon: Sentiment extraction from small talk on the web. Management science, 53(9). 1375-1388. DOI: http://dx.doi.org/10.1287/mnsc.1070.0704

10. David, H. (2015). Why are there still so many jobs? The history and future of workplace automation. Journal of economic perspectives, 29(3). 3-30. DOI: http://dx.doi.org/10.1257/jep.29.3.3 
11. Demiroz, F., \& Haase, T. W. (2019). The concept of resilience: a bibliometric analysis of the emergency and disaster management literature. Local Government Studies, 45(3). 308-327. DOI: http://dx.doi.org/10.1080/03003930.2018.1541796

12. Dirican, C. (2015). The impacts of robotics, artificial intelligence on business and economics. Procedia-Social and Behavioral Sciences, 195, 564-573. DOI: http://dx.doi.org/10.1016/j.sbspro.2015.06.134

13. Ehret, M., \& Wirtz, J. (2017). Unlocking value from machines: business models and the industrial internet of things. Journal of Marketing Management, 33(12). 111-130. DOI: http://dx.doi.org/10.1080/0267257X.2016.1248041

14. Fethi, M. D., \& Pasiouras, F. (2010). Assessing bank efficiency and performance with operational research and artificial intelligence techniques: A survey. European Journal of Operational Research, 204(2). 189-198. DOI: http://dx.doi.org/10.1016/j.ejor.2009.08.003

15. Fountain, T., McCarthy, B., \& Saleh, T. (2019). Building the AI-Powered Organization Technology isn't the biggest challenge, Culture is. Harvard Business Review, 97(4). 62. https://hbr.org/2019/07/building-the-ai-poweredorganization

16. Furrer, O., Thomas, H., \& Goussevskaia, A. (2008). The structure and evolution of the strategic management field: A content analysis of 26 years of strategic management research. International Journal of Management Reviews, 10(1). 123. DOI: http://dx.doi.org/10.1111/j.1468-2370.2007.00217.x

17. Grewal, D., Roggeveen, A. L., \& Nordfält, J. (2017). The future of retailing. Journal of Retailing, 93(1). 1-6. DOI: http://dx.doi.org/10.1016/j.jretai.2016.12.008

18. Holford, W. D. (2019). The future of human creative knowledge work within the digital economy. Futures, 105, 143-154. DOI: https://doi.org/10.1016/j.futures.2018.10.002

19. Huang, M. H., \& Rust, R. T. (2018). Artificial intelligence in service. Journal of Service Research,21(2). 155-172. DOI: http://dx.doi.org/10.1177/1094670517752459

20. Huang, M. H., Rust, R., \& Maksimovic, V. (2019). The Feeling Economy: Managing in the Next Generation of Artificial Intelligence (AI). California Management Review, 61(4). 43-65. DOI: http://dx.doi.org/10.1177/0008125619863436

21. Jain, A. S., \& Meeran, S. (1999). Deterministic job-shop scheduling: Past, present and future. European Journal of Operational Research, 113(2). 390434. DOI: http://dx.doi.org/10.1016/S0377-2217(98)00113-1 
22. Johnson, R., Watkinson, A. \& Mabe M. (2018) The STM Report: An overview of scientific and scholarly publishing, Fifth Edition [online]. The Hague: International Association of Scientific, Technical and Medical Publishers. Available at: https://www.stm-assoc.org/2018_10_04_STM_Report_2018.pdf [15.11.2019.]

23. Kane, G. C. (2017). The evolutionary implications of social media for organizational knowledge management. Information and organization, 27(1). 37-46. DOI: http://dx.doi.org/10.1016/j.infoandorg.2017.01.001

24. Kaplan, A., \& Haenlein, M. (2019). Siri, Siri, in my hand: Who's the fairest in the land? On the interpretations, illustrations, and implications of artificial intelligence. Business Horizons, 62(1). 15-25. DOI: http://dx.doi.org/10.1016/j.bushor.2018.08.004

25. Kliman, R., \& Arinze, B. (2019). Cognitive computing: Impacts on financial advice in wealth management. In Aligning business strategies and analytics (pp. 11-23). Springer, Cham. DOI: http://dx.doi.org/10.1007/978-3-319-93299-6_2

26. Kulkarni, U. R., \& Kiang, M. Y. (1995). Dynamic grouping of parts in flexible manufacturing systems - a self-organizing neural networks approach. European Journal of Operational Research,84(1). 192-212. DOI: 10.1016/03772217(94)00326-8

27. LeBaron, B., Arthur, W. B., \& Palmer, R. (1999). Time series properties of an artificial stock market. Journal of Economic Dynamics and control, 23(9-10). 1487-1516. DOI: http://dx.doi.org/10.1016/S0165-1889(98)00081-5

28. Makridakis, S. (2017). The forthcoming Artificial Intelligence (AI) revolution: Its impact on society and firms. Futures, 90, 46-60. DOI: http://dx.doi.org/10.1016/j.futures.2017.03.006

29. Marzi, G., Dabić, M., Daim, T., \& Garces, E. (2017). Product and process innovation in manufacturing firms: a 30-year bibliometric analysis. Scientometrics, 113(2). 673-704.

DOI: http://dx.doi.org/10.1007/s11192-017-2500-1

30. Nam, T. (2019). Technology usage, expected job sustainability, and perceived job insecurity. Technological Forecasting and Social Change, 138, 155-165. DOI: http://dx.doi.org/10.1016/j.techfore.2018.08.017

31. Sagiyeva, R., Zhuparova, A., Ruzanov, R., Doszhan, R., \& Askerov, A. (2018). Intellectual input of development by knowledge-based economy: problems of measuring in countries with developing markets. Entrepreneurship and Sustainability Issues, 6(2). 711-728. DOI: $\underline{\text { http://dx.doi.org/10.9770/jesi.2018.6.2(17) }}$ 
32. Sremac, S., Zavadskas, E. K., Matić, B., Kopić, M., \& Stević, Ž. (2019). Neurofuzzy inference systems approach to decision support system for economic order quantity. Economic Research-Ekonomska Istraživanja, 32(1). 1114-1137. DOI: http://dx.doi.org/10.1080/1331677X.2019.1613249

33. Storer, R. H., Wu, S. D., \& Vaccari, R. (1992). New search spaces for sequencing problems with application to job shop scheduling. Management science, 38(10), 1495-1509. DOI: https://doi.org/10.1287/mnsc.38.10.1495

34. Swaminathan, J. M., Smith, S. F., \& Sadeh, N. M. (1998). Modeling supply chain dynamics: A multiagent approach. Decision sciences, 29(3). 607-632. DOI: http://dx.doi.org/10.1111/j.1540-5915.1998.tb01356.x

35. Tam, K. Y. (1992). Genetic algorithms, function optimization, and facility layout design. European Journal of Operational Research, 63(2), 322-346. DOI: https://doi.org/10.1016/0377-2217(92)90034-7

36. Tam, K. Y., \& Kiang, M. Y. (1992). Managerial applications of neural networks: the case of bank failure predictions. Management science, 38(7). 926-947. DOI: http://dx.doi.org/10.1287/mnsc.38.7.926

37. Velencei, J. (2019). New human-machine relations request a new paradigm: understanding artificial intelligence. Economic and Social Development: Book of Proceedings, 451-458. https://search.proquest.com/docview/2188521211?accountid=132154

38. Warner, K. S., \& Wäger, M. (2019). Building dynamic capabilities for digital transformation: An ongoing process of strategic renewal. Long Range Planning, 52(3). 326-349. DOI: http://dx.doi.org/10.1016/j.lrp.2018.12.001

39. Wirtz, J., Patterson, P. G., Kunz, W. H., Gruber, T., Lu, V. N., Paluch, S., \& Martins, A. (2018). Brave new world: service robots in the frontline. Journal of Service Management, 29(5). 907-931. DOI: http://dx.doi.org/10.1108/JOSM04-2018-0119

40. Zhang, G., Hu, M. Y., Patuwo, B. E., \& Indro, D. C. (1999). Artificial neural networks in bankruptcy prediction: General framework and cross-validation analysis. European Journal of Operational Research, 116(1). 16-32. DOI: http://dx.doi.org/10.1016/S0377-2217(98)00051-4

41. Zhang, J., McBurney, P., \& Musial, K. (2018). Convergence of trading strategies in continuous double auction markets with boundedly-rational networked traders. Review of Quantitative Finance and Accounting, 50(1). 301-352. DOI: http://dx.doi.org/10.1007/s11156-017-0631-3 
Appendix 1. List of topics sorted by the number of their appearance

\begin{tabular}{|c|c|}
\hline Neural network & 196 \\
\hline Forecast & 132 \\
\hline Prediction & 121 \\
\hline Simulation & 113 \\
\hline Optimization & 112 \\
\hline Decision making & 104 \\
\hline Robot & 103 \\
\hline Decision support & 98 \\
\hline Expert system & 90 \\
\hline Big data & 87 \\
\hline Automation & 60 \\
\hline Agent*based & 59 \\
\hline Genetic algorithm & 55 \\
\hline Marketing & 55 \\
\hline Distribution & 52 \\
\hline Manufacturing & 52 \\
\hline Finance & 46 \\
\hline Data mining & 44 \\
\hline Time series & 44 \\
\hline Scheduling & 43 \\
\hline Heuristics & 36 \\
\hline Accounting & 32 \\
\hline Logistics & 30 \\
\hline Case*based reasoning & 26 \\
\hline Computer science & 25 \\
\hline Supply chain & 25 \\
\hline Support vector machine & 25 \\
\hline Banking & 24 \\
\hline Futures & 23 \\
\hline Operations research & 22 \\
\hline Pricing & 22 \\
\hline Sustainability & 21 \\
\hline Transportation & 21 \\
\hline Bankruptcy & 20 \\
\hline Decision analysis & 20 \\
\hline Financial markets & 20 \\
\hline
\end{tabular}

\begin{tabular}{|l|l|}
\hline Knowledge-based systems & 20 \\
\hline Natural language processing & 20 \\
\hline Social media & 20 \\
\hline Traffic & 20 \\
\hline Cloud computing & 19 \\
\hline Discriminant analysis & 19 \\
\hline Pattern recognition & 19 \\
\hline Clustering & 18 \\
\hline Computational intelligence & 18 \\
\hline Game theory & 18 \\
\hline Multi-agent system & 18 \\
\hline Risk management & 18 \\
\hline Credit risk & 17 \\
\hline Operational research & 17 \\
\hline Tourism & 17 \\
\hline Psychology & 16 \\
\hline Technological change & 16 \\
\hline Blockchain & 15 \\
\hline Data analytics & 15 \\
\hline Distributed artificial & 13 \\
\hline intelligence & 13 \\
\hline Knowledge acquisition & 15 \\
\hline Business intelligence & 14 \\
\hline Genetic programming & 14 \\
\hline Intelligent systems & 14 \\
\hline Military & 14 \\
\hline Negotiation & 14 \\
\hline Strategic planning & 13 \\
\hline Auditing & 13 \\
\hline Decision theory & 13 \\
\hline Deep learning & 13 \\
\hline E-commerce & 13 \\
\hline Financial crisis & 13 \\
\hline Hybrid model & 13 \\
\hline Reinforcement learning & 13 \\
\hline Virtual reality & 13 \\
\hline & 13 \\
\hline
\end{tabular}




\begin{tabular}{|l|l|}
\hline Bounded rationality & 12 \\
\hline Consumer behavior & 12 \\
\hline Entrepreneurship & 12 \\
\hline Financial institutions & 12 \\
\hline Intelligent agent & 12 \\
\hline Linear programming & 12 \\
\hline Probabilities & 12 \\
\hline Credit scoring & 11 \\
\hline Customer service & 11 \\
\hline Ensemble & 11 \\
\hline Industry 4.0 & 11 \\
\hline Knowledge discovery & 11 \\
\hline Knowledge representation & 11 \\
\hline Project management & 11 \\
\hline Risk assessment & 11 \\
\hline Singularity & 11 \\
\hline Artificial stock market & 10 \\
\hline Consciousness & 10 \\
\hline Exchange rate & 10 \\
\hline Financial ratios & 10 \\
\hline Tabu search & 10 \\
\hline Augmented reality & 9 \\
\hline Bayesian network & 9 \\
\hline Combinatorial optimization & 9 \\
\hline Decision trees & 9 \\
\hline Early warning & 8 \\
\hline Health care & 8 \\
\hline Mathematical programming & 9 \\
\hline Risk analysis & 9 \\
\hline Backpropagation & 8 \\
\hline Belief networks & 8 \\
\hline Classification accuracy & 8 \\
\hline Classification problem & 8 \\
\hline E-business & 8 \\
\hline Foresight & 8 \\
\hline Fourth industrial revolution & 8 \\
\hline Future of work & 8 \\
\hline
\end{tabular}

\begin{tabular}{|l|l|}
\hline Fuzzy sets & 8 \\
\hline Market microstructure & 8 \\
\hline Operations management & 8 \\
\hline Particle swarm optimization & 8 \\
\hline Personalization & 8 \\
\hline Process management & 8 \\
\hline Rough sets & 8 \\
\hline Search engine & 8 \\
\hline Sensitivity analysis & 8 \\
\hline ANFIS & 7 \\
\hline BPM & 7 \\
\hline Complex system & 7 \\
\hline Content analysis & 7 \\
\hline Cyberspace & 7 \\
\hline Evolutionary algorithms & 7 \\
\hline Human-computer interaction & 7 \\
\hline Intellectual capital & 7 \\
\hline Intuition & 7 \\
\hline Knowledge engineering & 7 \\
\hline Neural nets & 7 \\
\hline Organizational learning & 7 \\
\hline Retailing & 7 \\
\hline Simulated annealing & 7 \\
\hline Strategic management & 7 \\
\hline Tacit knowledge & 7 \\
\hline Cluster analysis & 6 \\
\hline Cognitive computing & 6 \\
\hline Dynamic programming & 6 \\
\hline Ecall & 6 \\
\hline EVOLINO & 6 \\
\hline Evolutionary computation & 6 \\
\hline Financial distress & 6 \\
\hline Fintech & 6 \\
\hline Influence diagrams & 6 \\
\hline Integer programming & 6 \\
\hline Knowledge economy & 7 \\
\hline Market research & 6 \\
\hline
\end{tabular}




\begin{tabular}{|l|l|}
\hline Multivariate statistics & 6 \\
\hline Q-learning & 6 \\
\hline Real estate & 6 \\
\hline Sentiment analysis & 6 \\
\hline Social networks & 6 \\
\hline Supervised learning & 6 \\
\hline Technical analysis & 6 \\
\hline Vehicle routing & 6 \\
\hline Ant colony optimization & 5 \\
\hline $\begin{array}{l}\text { Artificial general } \\
\text { intelligence }\end{array}$ & 5 \\
\hline Autonomous systems & 5 \\
\hline Business failure & 5 \\
\hline Chatbot & 5 \\
\hline Computational complexity & 5 \\
\hline Control systems & 5 \\
\hline
\end{tabular}

\begin{tabular}{|l|l|}
\hline $\begin{array}{l}\text { Corporate social } \\
\text { responsibility }\end{array}$ & 5 \\
\hline Double auction & 5 \\
\hline IBM watson & 5 \\
\hline Management support & 5 \\
\hline Metaheuristics & 5 \\
\hline Operational risk & 5 \\
\hline Performance evaluation & 5 \\
\hline Quality management & 5 \\
\hline Random forest & 5 \\
\hline Soft computing & 5 \\
\hline Speculation & 5 \\
\hline Swarm intelligence & 5 \\
\hline System dynamics & 5 \\
\hline Systems science & 5 \\
\hline Telecommunications & 5 \\
\hline Text mining & 5 \\
\hline
\end{tabular}




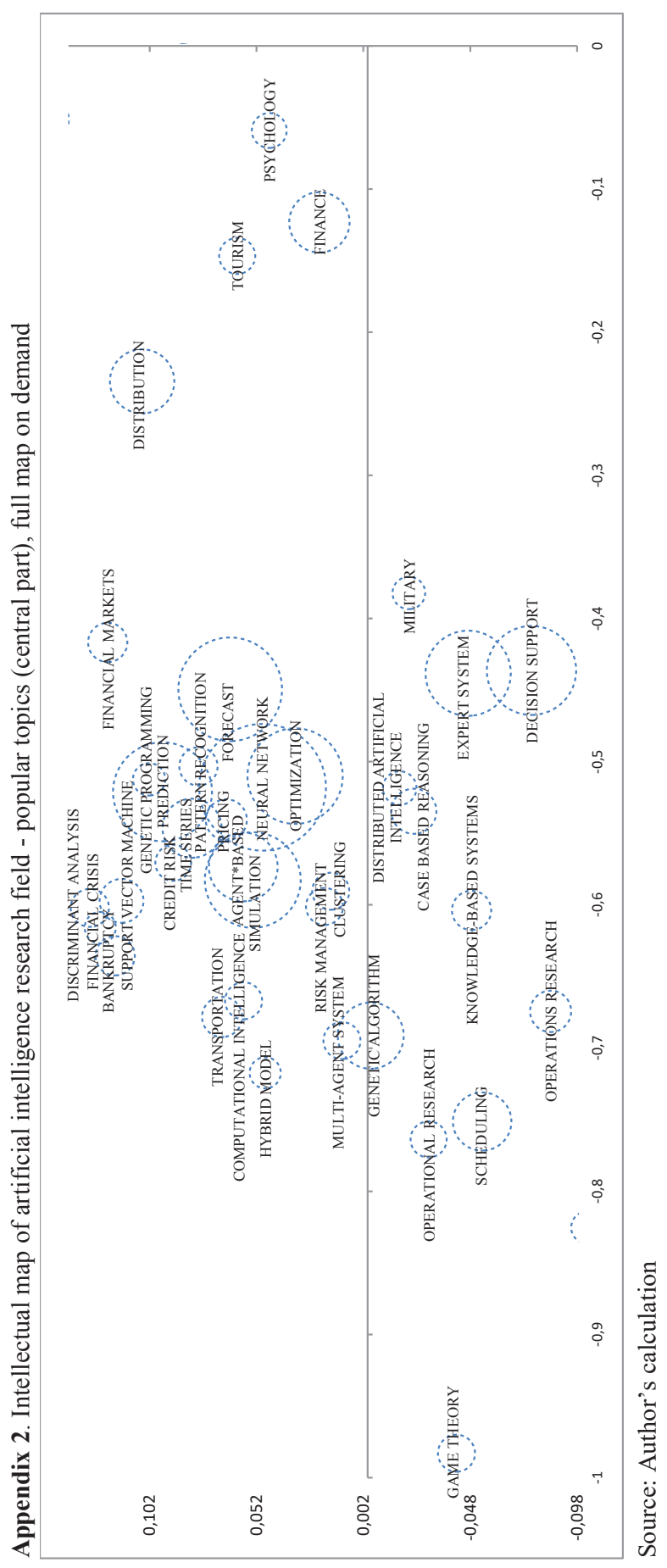




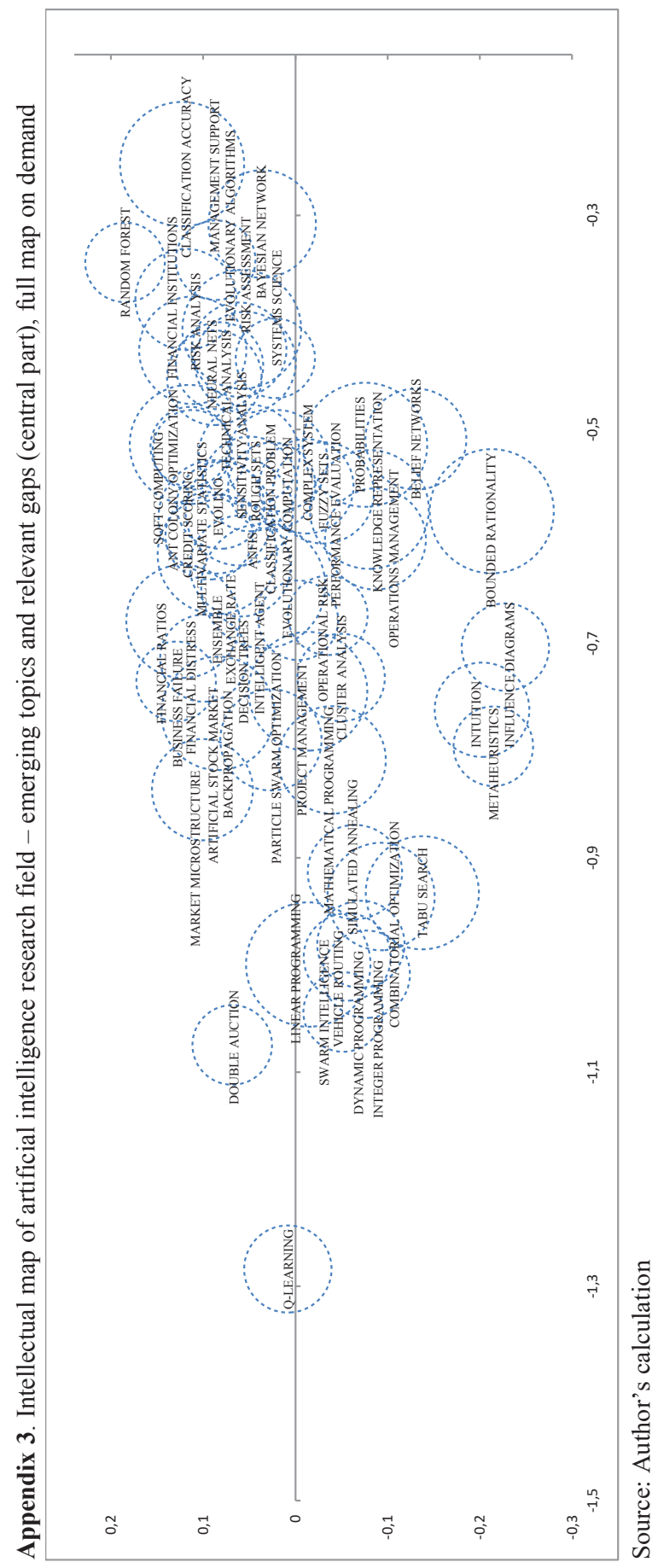




\section{BIBLIOMETRIJSKA ANALIZA UMJETNE INTELIGENCIJE U POSLOVNOJ EKONOMIJI}

\section{Ivan Novak}

\section{Sažetak}

Otkriće umjetne inteligencije zasigurno predstavlja jednu od najvažniji tehnoloških inovacija moderne ekonomije. Opća umjetna inteligencija koja može dosegnuti singularitet ima potencijal kreirati novu tehnološku arenu. Jednom otkrivena smatra se da će nadmašiti sve ljudske kognitivne sposobnosti. Nadalje, specifična umjetna inteligencija već je otkrivena $i$ primijenjena u brojnim sustavima. Ovaj rad nastoji istražiti područje umjetne inteligencije s naglaskom primjene u ekonomiji. Podaci su derivirani na osnovi zapisa Web of Science baze jednog od najrelevantnijih izvora znanstvenih radova. Ukupan broj ekstrahiranih zapisa u periodu 1963-2019 bio je 1369. Rezultati čine sustavan pregled najutjecajnijih autora, radova te izvora publikacija. Dodatno, koristeći MCA kreirana je intelektualna mapa istraživačkog područja.

Ključne riječi: umjetna inteligencija, poslovna ekonomija i ekonomija, analiza sadržaja, bibliometrija, HOMALS. 